\title{
Lymphocyte subset counts in skin puncture and venous blood compared
}

\author{
S E Cracknell, R F Hinchliffe, J S Lilleyman
}

\begin{abstract}
To determine whether skin puncture blood can be used reliably for CD4 lymphocyte counts, the numbers of the major subsets of lymphocytes were assessed in paired venous and skin puncture blood samples from 22 children and 10 adults. Paired values were highly correlated, with skin puncture values being about $7 \%$ higher than venous values for each cell type. Differences were of borderline statistical significance for total lymphocytes and for each subset except CD3 + CD8 + T lymphocytes. Nevertheless, the magnitude of the differences was small and unlikely to be of clinical importance, and it seems that skin puncture samples may be preferable for CD4 counts in children or adults with difficult venous access.

(f Clin Pathol 1995;48:1137-1138)
\end{abstract}

Keywords: Lymphocyte subsets, CD4, CD8.

The counting of lymphocyte subsets is widely used in the detection and monitoring of immunodeficiency states, and CD4 counts are frequently requested in patients with HIV infection. Flow cytometric analysis of the major subsets requires only a sample volume of $<1$ $\mathrm{ml}$, and this study was undertaken to determine whether skin puncture (capillary) blood is a suitable alternative to venous blood. If so, such a technique might be useful in paediatric practice.

Section of Paediatric Haematology,

University of

Sheffield Department

of Paediatrics,

The Children's

Hospital,

Western Bank,

Sheffield

S10 2THS

$S$ E Cracknell

R F Hinchliffe

J S Lilleyman

Correspondence to:

Dr R F Hinchliffe.

Accepted for publication 13 March 1995

\section{Methods}

Paired venous and skin puncture samples were taken from children being treated for acute leukaemia. Skin puncture samples taken for blood counts when attending an outpatient clinic were used, venous samples being taken around two hours later, at the time of routine administration of intravenous drugs. No child had blood taken simply for the purpose of this study. Paired samples were also taken from healthy adult volunteers.

Paired samples were treated identically. Lymphocyte subset numbers were determined by flow cytometry (FACScan, Becton Dickinson, Oxford, UK) using instrument defined gates (Simulset software version 2.3.2) and a panel of combined monoclonal antibodies (Simultest, Becton Dickinson). Instrument standardisation and methodology conformed to current guidelines. ${ }^{1}$ Absolute numbers of lymphocytes and their subpopulations were derived from an automated total white cell count and the three part differential provided by the FACScan. Statistical analysis was by the Wilcoxon signed rank test.

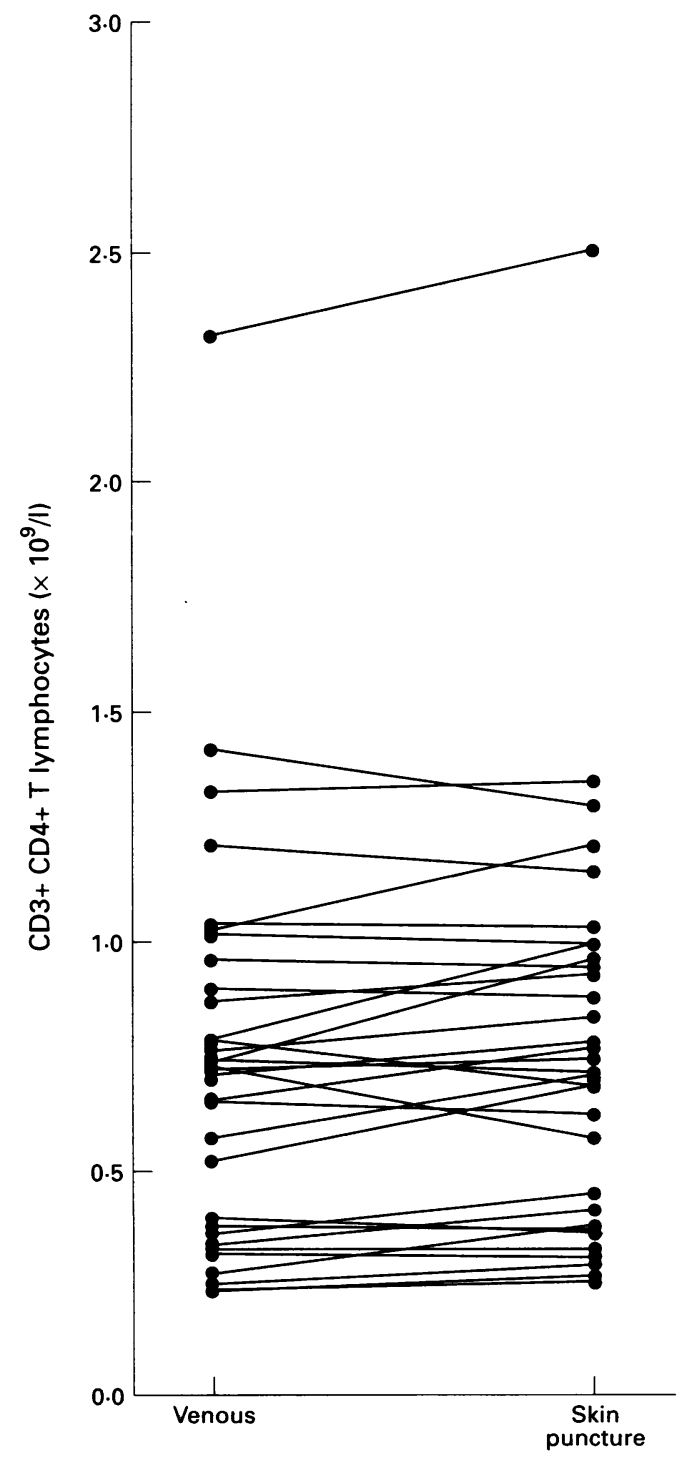

$C D 3+C D 4+T$ lymphocyte values in paired venous and skin puncture samples. 
Number of white cells, lymphocytes and lymphocyte subpopulations (median and range, $\times 10^{9} / 1$ ) in venous and skin puncture blood

\begin{tabular}{|c|c|c|c|c|c|c|c|}
\hline Sample type & $\begin{array}{l}\text { Total white } \\
\text { cells }\end{array}$ & Lymphocytes & $\begin{array}{l}C D 3+ \\
T \text { cells }\end{array}$ & $\begin{array}{l}C D 3+C D 4+ \\
T \text { cells }\end{array}$ & $\begin{array}{l}C D 3+C D 8+ \\
T \text { cells }\end{array}$ & $\begin{array}{l}\text { CD19+ } \\
B \text { cells }\end{array}$ & $\begin{array}{l}C D 3+C D 16+C D 56+ \\
\text { natural killer cells }\end{array}$ \\
\hline $\begin{array}{l}\text { Venous blood } \\
\text { Skin puncture } \\
\text { blood }\end{array}$ & $\begin{array}{l}4 \cdot 6 \\
(1 \cdot 3-13 \cdot 0) \\
4 \cdot 6 \\
(1 \cdot 6-14 \cdot 2)\end{array}$ & $\begin{array}{l}1 \cdot 46 \\
(0 \cdot 47-4 \cdot 45) \\
1 \cdot 51 \\
(0 \cdot 43-4 \cdot 62)\end{array}$ & $\begin{array}{l}1 \cdot 26 \\
(0 \cdot 38-3 \cdot 69) \\
1 \cdot 27 \\
(0 \cdot 41-3 \cdot 93)\end{array}$ & $\begin{array}{l}0 \cdot 71 \\
(0 \cdot 23-2 \cdot 31) \\
0 \cdot 74 \\
(0 \cdot 25-2 \cdot 50)\end{array}$ & $\begin{array}{l}0 \cdot 49 \\
(0 \cdot 12-1 \cdot 32) \\
0 \cdot 47 \\
(0 \cdot 09-1 \cdot 66)\end{array}$ & $\begin{array}{l}0.03 \\
(0-0 \cdot 36) \\
0 \cdot 03 \\
(0-0 \cdot 38)\end{array}$ & $\begin{array}{l}0 \cdot 10 \\
(0 \cdot 01-0 \cdot 42) \\
0 \cdot 14 \\
(0 \cdot 02-0 \cdot 48)\end{array}$ \\
\hline$p$ value & 0.009 & 0.03 & 0.036 & 0.033 & $0 \cdot 12$ & 0.05 & 0.049 \\
\hline
\end{tabular}

\section{Results}

Samples were obtained from 22 children aged from eight months to 16.4 years, median 5.5 years, and 10 adults aged between 26 and 44 years. Data from adults and children were combined for analysis. The numbers of the different cell types were higher in skin puncture blood $(4 \cdot 8-6 \cdot 4 \%$ higher for subsets other than CD3 + CD16 + CD56 + natural killer cells, which were $10 \cdot 7 \%$ higher), the difference being statistically significant for all cell types except CD3 + CD8 + T lymphocytes (table). Significance was lost for all pairings when total lymphocytes and subpopulations were expressed in proportional terms (data not shown). Paired values were highly correlated $(r=0.90$ for $\mathrm{CD} 3+\mathrm{CD} 16+\mathrm{CD} 56+$ natural killer cells, and 0.96-0.98 for total white cells, lymphocytes and other subsets, $p<0.0001$ for al pairings). The differences between paired $\mathrm{CD} 3+\mathrm{CD} 4+\mathrm{T}$ cell counts is shown in the figure.

\section{Discussion}

Collection of blood by skin puncture provides a rapid and simple alternative to venepuncture when small volumes of blood are required, and is useful when dealing with small children and subjects with difficult veins. In this study no undue difficulty was found in obtaining the required volume of skin puncture blood; should problems arise it may be possible to reduce test volumes by $25-50 \%$, at least when the total lymphocyte count is within normal limits.

Previous studies have shown clinically acceptable comparability in white cell and differential counts between the two samples types, ${ }^{23}$ although in the earlier study neutrophil values were significantly higher in skin puncture blood. Similar results were obtained in the present study, the usually slightly higher total white cell count of skin puncture samples being reflected proportionally throughout the range of lymphocyte subsets. Although of borderline statistical significance for most subpopulations, the magnitude of the difference was small and unlikely to be of clinical importance.

The precision of both replicate haemoglobin and platelet estimations from skin puncture samples has been reported to be poorer than that from venous blood, ${ }^{45}$ although the latter claim could not be verified using the same sample collection method as that of the present study. ${ }^{2}$ While we did not count lymphocytes in sequential paired samples there appears to be no reason why their numbers should fluctuate to a greater degree in skin puncture blood, a contention supported by the highly significant correlations found for each lymphocyte subpopulation between the two sample types.

Our results indicate that skin puncture blood can be safely used as an alternative to venous blood for the enumeration of CD4 and other lymphocyte subsets. It would be prudent when monitoring cell numbers over time, however, to use one sample type alone in order to minimise the variables affecting the results obtained.

1 Calvelli T, Denny TN, Paxton H, Galman R, Kagan J Guidelines for flow cytometric immunophenotyping: a report from the National Institute of Allergy and Infectious Diseases, Division of AIDS. Cytometry 1993;14:702-15. 2 Bellamy GJ, Hinchliffe RF. Venous and skin puncture blood counts compared. Clin Lab Haematol 1988;10:329-34.

Dreyer R, Pillay GS, Jacobs P. Skin puncture blood count [letter]. Clin Lab Haematol 1994;16:304-5.

4 Reeves JD, Vinchinsky E, Addiego J Jr, Lubin BH. Iron deficiency in health and disease. In: Barnes LA, ed. $A d$ vances in pediatrics. Chicago: Year Book Medical Publishers, 1983:281-319.

5 Brecher G, Schneiderman $M$, Cronkite EP. The reproducibility and constancy of the platelet count. $A m$ Clin Pathol 1953;23:15-26.
Department of Pathology, The Medical School, University of Birmingham, Edgbaston, Birmingham B15 2TT G M Reynolds D C Rowlands

IDRL Department of Immunology G P Mead

Correspondence to: Mr G M Reynolds.

Accepted for publication 1 June 1995

\section{Detection of Ki67 antigen by a new sheep polyclonal antiserum}

\author{
G M Reynolds, D C Rowlands, G P Mead
}

\author{
Abstract \\ This report describes the characterisation \\ of a polyclonal sheep antiserum against \\ the Ki67 antigen. On western blots, this \\ antiserum recognises a pair of bands of \\ high molecular weight identical with those
}

seen with another polyclonal Ki67 antiserum and the MIB 1 monoclonal antibody. The new antiserum showed nuclear staining of a proportion of cells in parafin wax embedded tissue sections following antigen retrieval using a microwave oven 